\title{
METHODOLOGICAL PRINCIPLES OF EVALUATION OF INVESTMENT ATTRACTIVENESS OF THE ENTERPRISE
}

\author{
Halyna Fyliuk', Kateryna Akulenko²
}

\begin{abstract}
The purpose of the research is a complex of theoretical and applied provisions on the formation, evaluation, and improvement of the methodology of evaluation of the investment attractiveness of enterprises. Methodology. In the process of research, the following methods were used: methods of comparison, analysis and synthesis is used in determining the features of conceptual approaches to the concept of investment attractiveness of an enterprise and the formation of the author's definition of this category; method of diagnostic evaluation is used in the evaluation of existing models for analysing the investment attractiveness of enterprises; method of expert evaluation is used for the building of flexible limits of levels of investment attractiveness of the enterprise; methods of system and structural analysis is used for developing the basic elements and the general structure of the model of interpretation of the method of graphical integration; the method of graphic integration is used within the construction of graphs of investment attractiveness of enterprises A and B. The aim of the study is to justify of the approach to create a model that can justify of the feasibility of investing and determine the factors and conditions of investment attractiveness of the enterprise for different participants of the investment process. The findings of the study. The results of the research suggested an improved definition of the concept of investment attractiveness of the enterprise, which took into account the following disadvantages of existing approaches to the present essence of the concept: the investment attractiveness of the enterprise is often associated with the system of financial and economic indicators of the activity of enterprise, while not taking into account also an important social and psychological factor, since the very name of the term "investment attractiveness of the enterprise" includes the social-psychological element in the form of the concept of "attractiveness", which is widely used in economic literature; the subjective view of the potential investor on the fact that the object being considered for investing to satisfy the investor's expectations regarding the economic or social effect is significant. This aspect is key in determining of concept of investment attractiveness of the enterprise, when choosing an investor of an enterprise to invest its capital for the purpose of investing; it is necessary to achieve consistency and symbiosis between the evaluation of financial and economic, socio-psychological, industrial, innovative, environmental and other factors, which in the complex form the investment attractiveness of the enterprise; using the expression "high level of profitability on investment with minimal risks" is partially incorrect in some definitions of the investment attractiveness of the enterprise since obtaining high profits involves a certain level of risk and each investor knows about this; the importance of increasing the investment attractiveness of the enterprise has the level of involvement of innovation in the activities of the enterprise in the frames of use of investment capital; the targeting of almost all definitions only on high financial and economic indicators, which, depending on the situation, are not always correct. A complex system of indicators for evaluation of the investment attractiveness of an enterprise is proposed, consisting of six groups of indicators (market position, property complex, profitability, financial stability, risks, innovative potential), each of which includes six coefficients determining the level of investment attractiveness for this group. The features and advantages of this system of indicators are: complexity and complementary to standard methods with indicators of the level of investment risk and innovative potential of enterprises; standardization of indicators; unidirectionality of indicators; Flexibility of the recommended limits for each coefficient. The method of graphical integration of the investment attractiveness of the enterprise, which has several advantages over other methods, proposed in the scientific literature, is offered because: it is a combination that includes the advantages of an integral method, as well as a market, and partially matrix method; it allows quantifying various aspects of economic activity of the enterprise by the elementary calculation of a certain number
\end{abstract}

\footnotetext{
Corresponding author:

${ }^{1}$ Taras Shevchenko National University of Kyiv, Ukraine.

E-mail: gfiluk@ukr.net

${ }^{2}$ Taras Shevchenko National University of Kyiv, Ukraine.

E-mail: ekaterina.akulenko@gmail.com
} 
of coefficients; it does not require significant time to spend on the evaluation; it has a mathematical justification since the final indicators for comparing the investment attractiveness of several enterprises are calculated using the numerical integration method; it has the flexibility of determining the level of investment attractiveness of an enterprise by incorporating into the methodology in accordance with the socio-psychological component of the concept of investment attractiveness and the interests of the investor; gives a visual interpretation of the results of investment attractiveness assessment.

Key words: investments, investment attractiveness of enterprise, complex evaluation of investment attractiveness, method of graphic integration, coefficients of investment attractiveness, profitability, financial stability, investment risk.

JEL Classification: D24, D25, C02, C18

\section{Introduction}

In order to attract investment resources effectively, every economic entity has to have an investment attractiveness, which enables it to realize its competitive potential completely, to expand and improve production activity, to implement innovations and results of Research \& Development (R\&D) in its activity, to have a positive impact on the growth of the attractiveness of the country's investment environment. In this regard, the first step in solving this task for the enterprise should be to determine the necessary parameters of the existing level of its investment attractiveness in the framework of one or another methodology. That is, there is a need for a qualitative and skilled integrated evaluation of the investment attractiveness of the enterprise in terms of a large number of parameters and components, which determine the level of investor interest in investing.

Despite the rather deep research of the mentioned problem, some of its aspects, in particular, those relating to the development of an effective methodology for assessing the investment attractiveness of an enterprise, have not yet been resolved, remain controversial and require further research.

In particular, a new aspect of the research of this topic is the innovative approach for evaluating of the investment attractiveness of enterprises, which involves using the model of interpretation of the method of graphical integration of the investment attractiveness of an enterprise to analyse the efficiency of investments. In addition, the complex system of indicators of investment attractiveness of the enterprise, which according to the proposed structure includes analysis of the market position, property complex, profitability, financial stability, riskiness and investment potential of the enterprise, has been improved and brought to a new level. Also, the approach to the concept of investment attractiveness of the enterprise was improved, which took into account the influence of modern concepts on the structure of this definition, in particular: the concept of integral assessment of enterprise indicators the concept of economic and psychological satisfaction of the investor, the concept of the complex of conditions and characteristics of the enterprise, the concept of the prospects of development of the enterprise, the concept of factor analysis, the efficiency of investment.
The methodological basis of the research is a complex of general scientific and special principles, provisions and methods of scientific research, the use of which is due to the goals and objectives, in particular, the methods of comparison, analysis and synthesis, the method of diagnostic evaluation, the method of expert evaluations, and the method of graphical integration.

Given the foregoing, the purpose of the study is to justify the approach to create a model that can justify the feasibility of investing and determine the factors and conditions of investment attractiveness of the enterprise for different participants in the investment process. This approach involves performing the following tasks: - definition of the essence and features of the concept of investment attractiveness of the enterprise in accordance with modern conceptual approaches;

- formation of a clear system of indicators for choosing the most effective directions for the investor from the point of view of external and internal conditions of investment;

- development of an effective methodology for complex analysis of investment attractiveness of the enterprise, which would combine the advantages of existing techniques, to be representative and practical for use in enterprises of any branch.

\section{Definition of investment attractiveness of the enterprise}

After reviewing and analysing existing approaches in science, and also having considered the definition of investment attractiveness of the enterprise considering the features of the identified concepts, we came to the following interpretation. We believe that the investment attractiveness of an enterprise should be interpreted as a complex indicator of the existing and potentially possible level of enterprise development, which is expressed in a set of conditions and characteristics of the enterprise's activities and in the system of integrated values that are reflecting the financial-economic, production, social, innovative, environmental, and legal aspects of the enterprise's activities and provide the investor's personal interest in investment in order to increase this investment or to obtain a social effect. 
The advantages of proposed definition are, firstly, the complexity of this determination and the consideration in its structure of all elements of the concepts found in the scientific literature, from the integral assessment and factor analysis, the conditions of the enterprise, to perspective approach and obligatory inclusion in the definition a socio-psychological component; secondly, the proposed definition takes into account not only the economic benefits of investment but also the social component, a high level of it can in some situations exceed several times the commercial effect.

\section{Methodology algorithm of evaluation of the investment attractiveness of the enterprise}

The theme of choosing the most effective method of evaluation of the investment attractiveness of an enterprise is still debatable for today. Since there is a large number of evaluation techniques of the investment attractiveness that can be divided into the following groups: evaluation of investment attractiveness of the enterprise on the basis of integral indicators of its financial condition; analysis of external information about the company through the use of a market approach; evaluation of internal and external characteristics of the enterprise through the use of a combined approach; evaluation based on an analysis of the uncertainty about future outcomes and opportunities and the expectations of these results presented by the strategic approach. All of these approaches do not exclude each other, so they can be combined in various interpretations, which help to expand the possibilities of evaluation of the enterprise in the framework of the analysis.

Based on the study of approaches, we propose a comprehensive methodology for evaluating the investment attractiveness of the enterprise. It includes elements of both integral, market, and combination approaches, each of it clearly shows the evaluation of the main results of the company's activities in the market. The basis of evaluation is the method of graphical integration that is a developed methodology that combines in the final version elements of matrix, graphics and mathematical analysis, which is its advantage.

Complex evaluation of investment attractiveness of the enterprise using method of graphics integration is shown below.

1. Selection of data for the analysis of the investigated enterprises by a complex system of indicators of investment attractiveness of the enterprise and carrying out of corresponding calculations. Indicators for analysis and the peculiarities of their application are considered within our research below.

2. Determination of boundaries for high and low investment attractiveness of enterprises by expert evaluation and considering recommended values of indicators. As well as determining the weight of each of the proposed six groups of indicators in accordance with the objectives of the investment project.

3. Construction of the model of investment attractiveness by bring in on the area high, medium, and low investment attractiveness levels and graphs of comparable enterprises in accordance with the 36 values of the calculated indicators and their analysis according to the received graphs (in what area of attractiveness is there for the most part a schedule for which groups of indicators the enterprise has weak or strong sides, etc.). This stage also includes the ability to build charts of the same company in a dynamic for several years to determine not only the current state of indicators but also their trends.

4. The final stage of evaluation of investment attractiveness involves determining the level of quantification using summary measure. That is an integral factor of the investment attractiveness of the enterprise, which is calculated by the method of numerical integration, and in particular, by the method of medium rectangles. This method implements the replacement of an integral by an integral sum that uses the value of a function in the middle points of elementary segments:

$$
\begin{aligned}
& y=\int_{a}^{b} f(x) d x \approx h \times \sum_{1=1}^{n} f\left(x_{i}\right) \approx h\left[y_{\frac{1}{2}}+y_{\frac{3}{2}}+\ldots+y_{\frac{1(2 n-1)}{2}}\right], \\
& x_{i}=a+i \times h-\frac{h}{2}
\end{aligned}
$$

where, $\mathrm{h}$ - the weight of the coefficient, and in the graphical interpretation - the value of the step.

The integration is performed using piecewise constant interpolation, each elementary interval to interval [a, $\mathrm{b}$ ] the function $\mathrm{f}(\mathrm{x})$ approaches a function that takes constant values. In other words, there is a summation of elementary squares of rectangles under the integral function curve.

\section{A complex system of indicators of investment attractiveness of the enterprise}

A complex system of indicators for the evaluation of investment attractiveness of the enterprise consists of six groups of indicators is offered. These groups are market position, property complex, profitability, financial stability, risks, innovative potential. Each of these groups includes six coefficients that determine the level of investment attractiveness according to this group (Table 1).

The peculiarities and advantages of this system of indicators in comparison with other options for evaluation techniques, found in the scientific literature, are:

- Complexity, which allows not analysing just individual elements of the efficiency of the company's operation, but obtaining a complete and general interpretation of all indicators that are important when making an investor decision; 
- Supplementation of standard methods by indicators of the level of investment risk and innovative potential of enterprises;

- All indicators of the enterprise are standardized and suitable for the analysis of the activity of the enterprise of any branch and legal form at the expense of using the method of determining the relative coefficients;

- That the interpretation of the results was correct in the system of indicators eliminated the possibility of their "versatility" by calculating the disintegrators as an inverse value;
- For each coefficient, there are two variants of limits: mathematical and recommended, in which the recommended limits are partially determined by the expert method for each individual project since the only recommended limit for these indicators does not exist. The closer or higher the coefficient to 1 , so is much better. This is due to the economic content of these indicators. If their value is high and the resources are fully involved, then is better the financial performance and greater the investment attractiveness of the enterprise.

Table 1

A complex system of indicators of investment attractiveness of an enterprise

\begin{tabular}{|c|c|c|c|c|}
\hline Symbol & $\begin{array}{l}\text { Indicators for evaluation } \\
\text { of the investment } \\
\text { attractiveness of an } \\
\text { enterprise }\end{array}$ & Formula & The essence of the symbols in the formula & $\begin{array}{l}\text { limits, } \\
\text { recommended } \\
\text { limits }\end{array}$ \\
\hline \multicolumn{5}{|c|}{ 1. Market position } \\
\hline $\mathrm{x} 1$ & $\begin{array}{l}\text { The coefficient of market } \\
\text { activity in the industry }\end{array}$ & $V p e \div V i$ & $\begin{array}{l}\text { Vpe - the volume of production of the enterprise, } \\
\text { units; } \\
\text { Vi - the volume of industry, units. }\end{array}$ & $\begin{array}{c}\quad[0 ; 1] \text {, } \\
\text { expert evaluation }\end{array}$ \\
\hline $\mathrm{x} 2$ & $\begin{array}{l}\text { The coefficient of market } \\
\text { power of the enterprise } \\
\text { (Lerner) }\end{array}$ & $\frac{P g-M e g}{P g}$ & $\begin{array}{l}\text { Pg - the price of goods, money units; } \\
\text { Meg - the marginal costs of goods produced, money } \\
\text { units; }\end{array}$ & $\begin{array}{c}(0 ; \infty] \\
\text { expert evaluation }\end{array}$ \\
\hline $\mathrm{x} 3$ & $\begin{array}{l}\text { The attractiveness of the } \\
\text { product for the consumer }\end{array}$ & $D \div S$ & $\begin{array}{l}\text { D - demand for products of a certain type, units; } \\
\text { S - supply of similar products on the market, units. }\end{array}$ & $\begin{array}{c}{[0 ; \infty]} \\
\text { expert evaluation }\end{array}$ \\
\hline $\mathrm{x} 4$ & $\begin{array}{l}\text { The ratio of the market } \\
\text { and book value of the } \\
\text { enterprise }\end{array}$ & $M v e \div E$ & $\begin{array}{l}\text { Mve - market value (capitalization) of enterprise, } \\
\text { money units; } \\
\text { E - equity, money units. }\end{array}$ & $\begin{array}{l}(0 ; \infty] \\
(1 ; \infty]\end{array}$ \\
\hline $\mathrm{x} 5$ & $\begin{array}{l}\text { The coefficient of growth } \\
\text { of the value of the } \\
\text { enterprise }\end{array}$ & $\frac{M v e * I A r}{R i+R r^{*}(1-\mathrm{P} e)}$ & $\begin{array}{l}\text { Mve - market value (capitalization) of the enterprise, } \\
\text { money units; } \\
\text { IAr - investment attractiveness of the region; } \\
\mathrm{Ri} \text { - return on investment, money units; } \\
\mathrm{Rr} \text { - the rate of return of capital, money units; } \\
\mathrm{Pe} \text { - the proportion of land in the total object cost, } \\
\text { money units. }\end{array}$ & $\begin{array}{l}(0 ; \infty] \\
(1 ; \infty]\end{array}$ \\
\hline $\mathrm{x} 6$ & Equity Ratio & $M s p \div P s$ & $\begin{array}{l}\text { Msp - market share price, money units; } \\
\text { Ps - proceeds per share, money units. }\end{array}$ & $\begin{array}{l}(0 ; \infty] \\
(1 ; \infty]\end{array}$ \\
\hline \multicolumn{5}{|c|}{ 2. Property complex } \\
\hline $\mathrm{x} 7$ & $\begin{array}{l}\text { The ratio of potential } \\
\text { gross income from real } \\
\text { estate and land }\end{array}$ & $\frac{A p l * R s q+A l l * R h a}{A i d}$ & $\begin{array}{l}\text { Apl - area of premises leased sq.m.; } \\
\text { All - land area, leased, ha; } \\
\text { Rsq - rental rate for } \\
1 \text { sq.m. money units; } \\
\text { Rha - rent per } 1 \text { ha, money units; } \\
\text { Aid - accrued interest on the deposit amount } \\
\text { invested in the bank, money units. }\end{array}$ & $\begin{array}{c}(0 ; \infty] \\
\text { expert evaluation }\end{array}$ \\
\hline $\mathrm{x} 8$ & Fixed asset refresh rate & $I v \div I c$ & $\begin{array}{l}\text { Iv - the initial value of fixed assets received during } \\
\text { the reporting period, money units; } \\
\text { Ic - the initial cost of fixed assets on the balance } \\
\text { sheet of the enterprise at the end of the period, } \\
\text { money units. }\end{array}$ & $\begin{array}{c}(0 ; \infty] \\
\text { expert evaluation }\end{array}$ \\
\hline $\mathrm{x} 9$ & Fixed assets ratio & $1-$ Noe $\div$ Tne & $\begin{array}{l}\text { Noe - the number of outdated equipment, } \\
\text { machinery and equipment, units; } \\
\text { Tne - total number of equipment, machinery and } \\
\text { equipment, units. }\end{array}$ & $\begin{array}{c}{[0 ; 1]} \\
{[0,5 ; 1]}\end{array}$ \\
\hline $\mathrm{x} 10$ & $\begin{array}{l}\text { The factor of production } \\
\text { potential }\end{array}$ & $\frac{V f+V c}{B c}$ & $\begin{array}{l}\mathrm{Vf} \text { - the value of fixed assets, money units; } \\
\mathrm{Vc} \text { - the value of current assets, money units; } \\
\mathrm{Bc} \text { - balance currency, money units. }\end{array}$ & $\begin{array}{c}(0 ; 1] \\
\text { expert evaluation }\end{array}$ \\
\hline
\end{tabular}


(Continuation of Table 1)

\begin{tabular}{|c|c|c|c|c|}
\hline $\mathrm{x} 11$ & Constant asset ratio & $N A c \div E$ & $\begin{array}{l}\text { NAc - non-current assets, money units; } \\
\text { E - equity, money units. }\end{array}$ & $\begin{array}{c}\quad(0 ; 1] \\
\text { expert evaluation }\end{array}$ \\
\hline $\mathrm{x} 12$ & $\begin{array}{l}\text { The coefficient of } \\
\text { territorial attractiveness }\end{array}$ & $1-(D c \div T c)$ & $\begin{array}{l}\text { Dc -distribution costs, money units; } \\
\text { Tc - total costs, money units }\end{array}$ & $\begin{array}{l}{[0 ; 1]} \\
{[0,5 ; 1]}\end{array}$ \\
\hline \multicolumn{5}{|c|}{ 3. Profitability } \\
\hline $\mathrm{x} 13$ & Total profitability ratio & $S i \div P c s$ & $\begin{array}{l}\mathrm{Si} \text { - sales income (works, services), money units; } \\
\text { Pcs - production costs for sales (its production cost), } \\
\text { money units. }\end{array}$ & $\begin{array}{l}x \in \infty \\
(0 ; \infty]\end{array}$ \\
\hline $\mathrm{x} 14$ & Rate of return & $\frac{S i}{A a f+A a c}$ & $\begin{array}{l}\mathrm{Si} \text { - sales income (works, services), money units; } \\
\text { Aaf, Aac - average annual cost respectively of fixed } \\
\text { and current assets, money units }\end{array}$ & $\begin{array}{l}x \in \infty \\
(0 ; \infty]\end{array}$ \\
\hline $\mathrm{x} 15$ & $\begin{array}{l}\text { Return on financial } \\
\text { investments }\end{array}$ & $N p \div F i$ & $\begin{array}{l}\mathrm{Np} \text { - Net profit (loss), money units; } \\
\text { Fi - financial investments, money units. }\end{array}$ & $\begin{array}{l}\mathrm{x} \in \infty \\
{[0 ; \infty]}\end{array}$ \\
\hline $\mathrm{x} 16$ & Return on equity ratio & $N p \div E$ & $\begin{array}{l}\mathrm{Np} \text { - net profit (loss), money units; } \\
\mathrm{E} \text { - equity, money units. }\end{array}$ & $\begin{array}{l}x \in \infty \\
(0 ; \infty]\end{array}$ \\
\hline $\mathrm{x} 17$ & Return on assets ratio & $N p \div B c$ & $\begin{array}{l}\mathrm{Np} \text { - net profit (loss), money units; } \\
\mathrm{Bc} \text { - balance currency, money units. }\end{array}$ & $\begin{array}{l}x \in \infty \\
(0 ; \infty]\end{array}$ \\
\hline $\mathrm{x} 18$ & Rate of return on business & $N p \div N i$ & $\begin{array}{l}\mathrm{Np} \text { - net profit (loss), money units; } \\
\mathrm{Ni} \text { - net income from sales of products (goods, } \\
\text { works, services), money units. }\end{array}$ & $\begin{array}{l}x \in \infty \\
(0 ; \infty]\end{array}$ \\
\hline \multicolumn{5}{|c|}{ 4. Financial stability } \\
\hline x19 & $\begin{array}{l}\text { The coefficient of financial } \\
\text { stability }\end{array}$ & $E \div D e p$ & $\begin{array}{l}\text { E - equity, money units; } \\
\text { Dep - debt capital, money units. }\end{array}$ & $\begin{array}{c}\quad(0 ; \infty] \\
\text { expert evaluation }\end{array}$ \\
\hline $\mathrm{x} 20$ & Financial stability ratio & $\frac{E+L t l}{B c}$ & $\begin{array}{l}\text { E - equity, money units; } \\
\text { Ltl - Long-term liabilities, money units; } \\
\text { Bc - balance currency, money units. }\end{array}$ & $\begin{array}{c}(0 ; 1] \\
{[0,5 ; 0,9]}\end{array}$ \\
\hline $\mathrm{x} 21$ & $\begin{array}{l}\text { The coefficient of } \\
\text { maintenance of own } \\
\text { working capital }\end{array}$ & $\frac{C a-C l}{C a}$ & $\begin{array}{l}\mathrm{Ca} \text { - current assets, money units; } \\
\mathrm{Cl} \text { - current liabilities, money units. }\end{array}$ & $\begin{array}{c}(0 ; 1] \\
{[0,5 ; 0,9]}\end{array}$ \\
\hline $\mathrm{x} 22$ & Equity to total assets ratio & $E \div B c$ & $\begin{array}{l}\text { E - equity, money units; } \\
\text { Bc - balance currency, money units. }\end{array}$ & $\begin{array}{l}(0 ; 1] \\
{[0,5 ; 1]}\end{array}$ \\
\hline $\mathrm{x} 23$ & $\begin{array}{l}\text { The coefficient of } \\
\text { investment of own and } \\
\text { long-term borrowings }\end{array}$ & $N A c \div M l t$ & $\begin{array}{l}\text { NAc - non-current assets, money units; } \\
\text { Mlt - means of long-term use, money units. }\end{array}$ & $\begin{array}{c}(0 ; 1] \\
{[0,4 ; 0,9]}\end{array}$ \\
\hline $\mathrm{x} 24$ & $\begin{array}{l}\text { Current assets to equity } \\
\text { ratio }\end{array}$ & Owe $\div E$ & $\begin{array}{l}\text { Owe - own working capital, money units; } \\
\text { E - equity, money units. }\end{array}$ & $\begin{array}{c}(0 ; 1] \\
{[0,25 ; 0,9]}\end{array}$ \\
\hline \multicolumn{5}{|c|}{ 5. Risks } \\
\hline $\mathrm{x} 25$ & $\begin{array}{l}\text { Bankruptcy probability } \\
\text { factor (Taffler) }\end{array}$ & $\begin{array}{l}0,53 * y 1+0,13 * \\
y 2+0,18 * \\
y 3+0,16 * y 4\end{array}$ & $\begin{array}{l}\text { y1 - profitability; } \\
\text { y2 - working capital adequacy; } \\
\text { y3 - financial risk; } \\
\text { y4 - liquidity of the enterprise; }\end{array}$ & $\begin{array}{l}x \in \infty \\
(0,3 ; \infty]\end{array}$ \\
\hline $\mathrm{x} 26$ & Absolute liquidity ratio & $\frac{C}{C l+F i n}$ & $\begin{array}{l}\mathrm{C} \text { - cash and cash equivalents, money units; } \\
\mathrm{Cl} \text { - current liabilities, money units. } \\
\text { Fin - future income, money units. }\end{array}$ & $\begin{array}{l}{[0 ; \infty]} \\
(0,2 ; 0,5]\end{array}$ \\
\hline $\mathrm{x} 27$ & Country risk index & $I C R \div 100$ & $\begin{array}{l}\text { ICR - country risk index ICRG - the general index, } \\
\text { determined on a 100-point scale based on } 22 \\
\text { components of risk, approaching } 100 \text { is the lowest risk. }\end{array}$ & $\begin{array}{l}{[0 ; 1]} \\
\text { expert evaluation }\end{array}$ \\
\hline $\mathrm{x} 28$ & $\begin{array}{l}\text { Financial transparency } \\
\text { and disclosure }\end{array}$ & $A v r \div S \max$ & $\begin{array}{l}\text { Avr - average arithmetic mean of the points made by } \\
\text { experts for the transparency of disclosure; } \\
\text { Smax - maximum score on which the scale of the } \\
\text { phenomenon is estimated (10 points) }\end{array}$ & $\begin{array}{l}{[0 ; 1]} \\
\text { expert evaluation }\end{array}$ \\
\hline $\mathrm{x} 29$ & $\begin{array}{l}\text { The coefficient of } \\
\text { diversification of activities } \\
\text { of the enterprise }\end{array}$ & $1-\frac{\sum_{i=1}^{n} S a(2 S n-1)}{100 \%}$ & $\begin{array}{l}\text { Sa - the share of thec i-th type of activity in the } \\
\text { structure of commodity products of the enterprise, \%; } \\
\text { Sn - serial number of the type of activity by the } \\
\text { volume of commodity products in the ranked row, } \\
\text { constructed according to the downward principle. }\end{array}$ & $\begin{array}{l}(0 ; 1) \\
\text { expert evaluation }\end{array}$ \\
\hline $\mathrm{x} 30$ & $\begin{array}{l}\text { Ratio of enterprise } \\
\text { compliance market needs }\end{array}$ & $V s \div T s$ & $\begin{array}{l}\text { Vs - the volume of sales of products that was } \\
\text { renewed or improved, unit; } \\
\text { Ts - total sales on the market, money units. }\end{array}$ & $\begin{array}{l}{[0 ; 1]} \\
\text { expert evaluation }\end{array}$ \\
\hline
\end{tabular}


(End of Table 1)

\begin{tabular}{|c|c|c|c|c|}
\hline \multicolumn{5}{|c|}{ 6. Innovative potential } \\
\hline $\mathrm{x} 31$ & $\begin{array}{l}\text { Employment rate by } \\
\text { innovative staffing }\end{array}$ & $\mathrm{Ne} \div$ Emav & $\begin{array}{l}\mathrm{Ne} \text { - the number of employees employed in the } \\
\text { innovation sector, people; } \\
\text { Emav - average number of employees of the } \\
\text { enterprise, people. }\end{array}$ & $\begin{array}{c}{[0 ; 1]} \\
\text { expert evaluation }\end{array}$ \\
\hline$x 32$ & $\begin{array}{l}\text { The coefficient of product } \\
\text { update }\end{array}$ & $P n \div O t$ & $\begin{array}{l}\text { Pn - the volume of production of new products; } \\
\text { Ot - total volume of output, units. }\end{array}$ & $\begin{array}{c}{[0 ; 1]} \\
\text { expert evaluation }\end{array}$ \\
\hline $\mathrm{x} 33$ & $\begin{array}{l}\text { The ratio of investing in } \\
\text { innovation }\end{array}$ & $F i a \div T i$ & $\begin{array}{l}\text { Fia - the amount of funds allocated for innovation } \\
\text { activity, money units; } \\
\text { Ti - total investment, money units. }\end{array}$ & $\begin{array}{c}{[0 ; 1] \text {, }} \\
\text { expert evaluation }\end{array}$ \\
\hline $\mathrm{x} 34$ & $\begin{array}{l}\text { The coefficient of } \\
\text { innovation degree }\end{array}$ & $I r \div I t$ & $\begin{array}{l}\text { Ir - the number of innovations, brought to the } \\
\text { realization (innovations), pcs; } \\
\text { It - the total number of innovations, pcs. }\end{array}$ & $\begin{array}{c}{[0 ; 1]} \\
\text { expert evaluation }\end{array}$ \\
\hline $\mathrm{x} 35$ & $\begin{array}{l}\text { The coefficient of } \\
\text { innovation product sales }\end{array}$ & Pin $\div$ Pcom & $\begin{array}{l}\text { Pin - the volume of innovative products, units; } \\
\text { Pcom - the volume of commodity products, units. }\end{array}$ & $\begin{array}{c}{[0 ; 1]} \\
\text { expert evaluation }\end{array}$ \\
\hline $\mathrm{x} 36$ & $\begin{array}{l}\text { The ratio of research and } \\
\text { development costs }\end{array}$ & Erd $\div$ Eia & $\begin{array}{l}\text { Erd - the amount of research and development } \\
\text { expenses, money units; } \\
\text { Eia - the amount of expenses for innovation activity, } \\
\text { money units. }\end{array}$ & $\begin{array}{c}{[0 ; 1] \text {, }} \\
\text { expert evaluation }\end{array}$ \\
\hline
\end{tabular}

Source: developed by the author using sources (Arancii, 2011; Budnikova, 2012; Davidenko, Buryak, Demyanenko, 2018; Kaji, Edelman, Khan, 2018; Kakhovska, 2018; Marhaichuk, 2012; Rzayeva, 2016; Skaluk, 2016; Tkachenko, 2013; Umerev. 2013; Volkova, 2016)

The practical value of the proposed integrated system of investment attractiveness indicators for the enterprise is due to the fact that the data regarding the level of investment attractiveness are the basis for assessing the necessary types and volumes of resources and determining the directions of further development of the enterprise.

\section{Interpretation of the method of graphic integration of the investment attractiveness of the enterprise}

For practical interpretation of the results using the proposed model, compare the investment attractiveness of enterprises $\mathrm{A}$ and $\mathrm{B}$. The initial conditions for construction are the distribution of levels of investment attractiveness in accordance with the standard recommended limits of indicators and average market values. An important moment in constructing this model and calculating the results by the formula for numerical integration is the use of a constant step $h_{i}=h=$ const, $(\mathrm{i}=1,2 \ldots 36)$. That is, the investor, in this case, gives equal importance to all indicators that characterize the investment attractiveness of the enterprise (Figure 1).

As can be seen from Figure 1, the investment attractiveness of enterprise B is significantly higher, compared with the enterprise A. It shows the graph curve, which predominantly lies in the medium and high investment attractiveness, while the location of curve A prevails in the area of low investment attractiveness, and only the indicators of profitability and low risk of investing may be of interest to the investor. In this case, it is clear that, according to the calculation results, the integral coefficient of enterprise A will be lower than the integral coefficient of enterprise $B$, since graphically the results of calculating the integrals are equal to the area below the graphs figures under investment attractiveness of enterprises A and B. In this case, there is no doubt that the area of the figure under the schedule of enterprise $\mathrm{B}$ is greater than under the schedule of enterprise A. The accuracy of using the formula of the middle rectangles reflects the area filled with rectangles under the schedule of the enterprise A. Miscalculation, which is determined by the calculations of the integral shows the fraction of non-consideration of those parts of the rectangles that are above the schedule of enterprise A. Thus, according to the results of the comparison of the enterprises, the investor will give advantage to the project $B$.

\section{Advantages of the method of graphics integration of investment attractiveness of the enterprise}

The main advantages of the method of graphic integration of the investment attractiveness of the enterprise to other methods proposed in the scientific literature are that:

1. This method is combined, it includes the advantages of an integral method, as well as a market and partially matrix method, by splitting the plane of construction of investment attractiveness graphs into separate quantitatively defined zones.

2. It allows quantitatively evaluating various aspects of the economic activity of the enterprise by the elementary calculation of a certain number of coefficients that most completely characterize the current state of the investment object. The system of coefficients, which is the basis of the calculation of the resulting integral coefficient, does not contain specific parameters, which makes it possible to compare enterprises of different industries. 


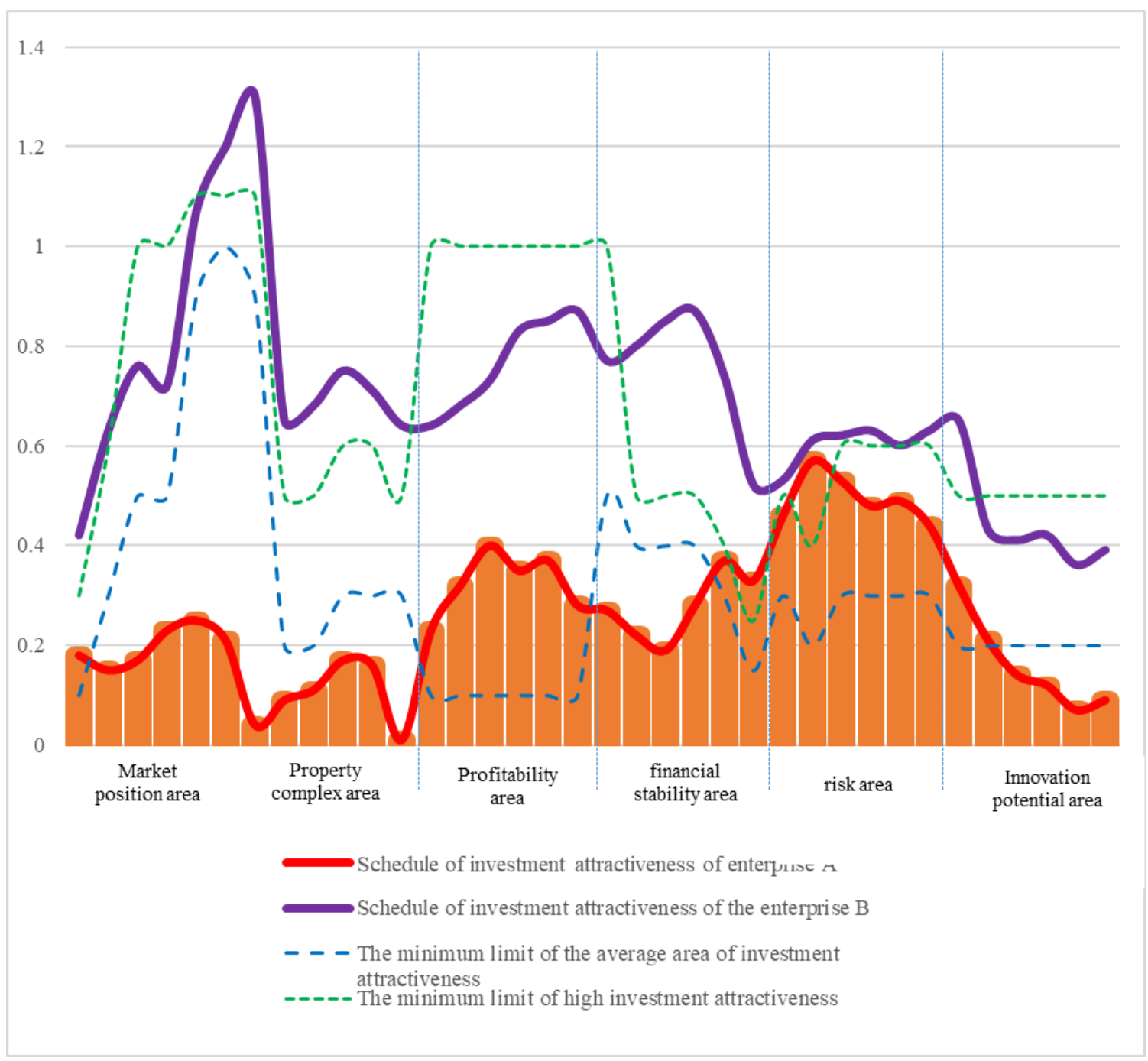

Figure 1. Model of interpretation of the method of graphical integration of investment attractiveness of the enterprise

Source: developed by the author

3. This method does not require significant time to spend on the evaluation, in addition, the calculation of parameters and construction of the model interpretation method can be automated at each enterprise by using a package of standard computer programs.

4. It has a mathematical justification, the final indicators for comparing the investment attractiveness of several enterprises are calculated by numerical integration method, namely, the method of rectangles and are quantified and compared. In addition, for the interpreted results a mathematical tolerance is determined. Of course, to avoid completely the approximate estimates (namely, expert evaluations of markets comparison) in the methodology is not possible, in particular, because the term "investment attractiveness" itself is not frustrated of subjectivism. However, these methods are used exclusively to determine the limits of distribution of low, medium, and high investment attractiveness zones, which for each investor, depending on the investment objectives, environmental conditions and other factors, are different.

5. The flexibility of determining the level of investment attractiveness of an enterprise by incorporating into the methodology, in accordance with the sociopsychological component of the concept of investment attractiveness, the interests of the investor, in particular the possibility of adjusting the limits between the levels of investment attractiveness of an enterprise, and the importance of groups of coefficients, depending on the direction and purpose of investment. So, in our opinion, the use of strict frameworks, as it normally used in most of the matrix approach by analysis of investment attractiveness, is not correct since the division of the scale on the three, for example (low, medium, and high level) are clear equidistant from the maximum and minimum quadrant, and it is not a justification for concluding that for example, an enterprise is not attractive to investors. After all, in the vast majority of techniques, the influence 
of external factors, the specifics of the industry is not taken into account, and therefore, the actual values of the indicators may be far from standardized reference, however, subject to modifications to the specifics of the environment or investment objectives, acceptable to the investor. Thus, if the investor's purpose is the presence of a large area of land, buildings and structures, in particular plants and large industrial premises, for the enterprises investment project implementation, which is the prerogative of investment, the profitability indicators of the enterprise practically will not matter, even on the contrary, investing in an unprofitable enterprise may even be on more favourable terms for the investor.

6. A clear interpretation of the results of an investment attractiveness evaluation, which is a significant advantage, since this model is based on the principle of simple use, the availability of the interpretation of results, and does not require specific economic knowledge to understand the result of research, which at times raises its practical significance for use at domestic enterprises of all spheres and branches of activity. In addition, the use of this graphical model allows not only comparing several enterprises on a plane and determining the best option for investment but also following changes in the schedule of investment attractiveness of the enterprise in the dynamics, which will allow identifying the weaknesses of the economic activity of the enterprise more quickly.

7. In order to provide a more comprehensive analysis, it was taken into account additionally to the most frequently used indicators for evaluation the investment attractiveness of the company, as profitability, financial status of the company and market indicators, such important determinants as investment risk and innovative potential of the enterprise and a system of coefficients for their evaluation was developed.

The practical value of the proposed methodological toolkit for the enterprise is due to the fact that the data regarding the investment attractiveness of the enterprise are the basis for evaluating the necessary types and volumes of resources that the investor must own in order to implement his investment project and ensure the strategic level of enterprise development. In general, the use of this model for evaluation the investment attractiveness of an enterprise allows providing an objective description of the financial and economic processes and capabilities of the enterprise, determining trends and dynamics of its development, establishing ways to improve the efficiency of the enterprise taking into account a certain divergence of objectives of the investor and the enterprise as a whole; identifying and liquidating factors that reduce the investment attractiveness of domestic enterprises and, as a result, the investment attractiveness of industries, regions and the country as a whole; on the basis of the obtained results of investment attractiveness evaluation to determine the main directions for investment of funds in order to improve the economic activity of the enterprise, increase its efficiency and competitiveness on the market.

\section{Conclusions}

The need for continuous development requires from enterprises a large number of regular investments, both in fixed assets and on R\&D, also on other goals aimed at achieving the most positive result. The ability to attract an investment directly depends on the level of investment attractiveness of the enterprise. Based on the extremely high significance of this process for the development of the enterprise, the determination of its investment attractiveness should be directed towards the formation of objective, purposeful, and comprehensive information for acceptance an investment decision.

Therefore, during considering the investment attractiveness of the enterprise, it is expedient to use the complex definition proposed by us since its components completely reflect the activity of the evaluated enterprise, take into account the socio-psychological factors and interests of all subjects of the investment process, while not depriving elements of financial and perspective analysis.

Based on the specifics of the definition and the results of comparing different methods of evaluation of the investment attractiveness of the enterprise in the scientific literature, we have proposed a method of graphical integration of investment attractiveness of the enterprise, which has a number of advantages over existing methods: complexity and combination, simplicity and insignificant expenses of time for calculations and model construction, mathematical substantiation, visual interpretation of evaluation results, flexibility of the limits of determining the level of investment attractiveness by taking into account the interests of the investor and the influence of external factors, completing the method of estimation of investment risk and the level of innovation potential of the enterprise. The practical value of the graphical integration method of investment attractiveness for an enterprise is that on the basis of the obtained evaluation results it becomes possible to separate the main directions for investment of funds with the purpose of the most effective realization of the investment project, improvement of economic activity of the enterprise, increase of its efficiency and competitiveness on the market.

Prospects for further research are the development and improvement of the methodology by taking into account the more fully factors of the influence of the environment and the specifics of the region and industry in particular, through qualitative and quantitative evaluation, and the inclusion in the model of the possibility of calculating forecast indicators under the terms of investing a certain amount of investment in one or another sphere of activity of enterprise. 


\section{References:}

Aranchy, D. S., Goncharenko, S. A. (2011). Investment attractiveness of enterprises: the essence, factors of influence and evaluation of existing methods of analysis. Scientific works of the Poltava State Agrarian Academy, 3(2), 59-64.

Budnikova, U. V. (2012). Methodology for assessing the investment attractiveness of enterprises. Economic analysis, 11(2), 67-70.

Davydenko, N., Buriak, A., Demyanenko, I. (2018). Investment attraction of the agricultural sector of the Ukrainian region in the contemporary conditions of socio-economic development. Baltic Journal of Economic Studies, 4(1), 106-110. doi: 10.30525/2256-0742/2018-4-1-106-110

Kaji, J., Edelman, K., Khan A. et al. (Eds). (2018). Growth of the Social Enterprise 2018 Deloitte Global Human Capital Trends. Deloitte Development LLC. Retrieved from: https://www2.deloitte.com

Kakhovskaya, E., Lositskaya, T., Kolesnikova, K. (2018). Economic efficiency of investment in development of enterprises staff. Baltic Journal of Economic Studies, 3(4), 115-122.

Marhaichuk, M. M. (2012). Analysis of investment attractiveness assessment methods in the context of innovative enterprise development. Marketing and innovation management, 4, 330-336.

Rzayeva, T. G., Gritsyuk, M. V. (2016). Indicators of estimation and analysis of investment attractiveness of the enterprise in the context of existing methods. Economic sciences. Bulletin of the Khmelnytsky National University, 3(1), 94-102.

Skaluk, R. V., Loic, O. I. (2016). Evaluation of investment attractiveness. Economic sciences. Bulletin of the Khmelnytsky National University, 1, 115-122.

Tkachenko, A. M., Kushnir, O. V. (2013). Economic assessment of the investment attractiveness of the enterprise. Bulletin of the Zaporizhzhya State Engineering Academy, 5, 154-161.

Umeerov, R. E. (2013). Formation of investment attractiveness of small and medium-sized enterprises in conditions of uncertainty of the competitive environment. Actual problems of the economy, 11, 90-94.

Volkova, N. A. (2016). Determination of criteria for assessing the investment attractiveness of agribusiness enterprises. Economic analysis: collection of scientific works of the Ternopil National Economic University, 2(23), 22-26. 